\title{
Law enforcement against trade in counterfeit goods using well-known marks (a study in traditional markets in Medan)
}

Aflah $^{*}$

Doctoral Program in Law, Graduate School, Faculty of Law, Universitas Sumatera Utara, Medan, Indonesia.

\begin{abstract}
The illegal use of well-known marks for counterfeit goods is qualified as a criminal act. The act may cause damages to the owner of a well-known mark. The protection of a registered mark and a well-known mark through Law Number 15 Year 2001 on Trade Marks should be able to address issues related to mark infringement. The number of cases of illegal use of well-known marks is high because, in a business, using a well-known mark is more profitable than using own mark. Other factor which influences trade in counterfeit goods using well-known marks is the lack of public legal awareness as consumers, producers and traders. An empirical research method was applied in the research, using primary and secondary data. Maximizing trade in local goods using registered marks is one of effective ways to minimize trade in counterfeit goods using wellknown marks in traditional markets in Medan. There are two possible solutions to this problem. The first solution is socializing Law on Marks to local producers, consumers and traders. The second solution is implementing a supporting program to help local producers register their rights to a mark.
\end{abstract}

\section{Introduction}

The function of mark is as a sign which is used on goods produced by a person or by several persons jointly or a legal entity to distinguish the goods from other goods of the same kind. It also can be used as promotion media. A product can be easily promoted by mentioning its mark and quality warranty. It can be a goodwill, emblem, quality standard and selling value in different types of market. It also can give satisfaction, pride and good reputation to consumers [1].

As one of intellectual properties, mark plays a vital role in good and service trades and investment. Mark having a good brand image can meet consumers' need to self-identity and is a warranty of the quality of goods and services in the free competition. Therefore, it becomes an economic asset for its owner - an individual or a company - which can give them great benefit as long as they take the good business and management aspects into account [2].

\footnotetext{
* Corresponding author : aflah@usu.ac.id
} 
Act Number 15 Year 2001 on Marks requires producers and holders of right to a mark to register their mark to ensure that they will get legal protection for goods or services they sell. It is vital to protect the rights to a mark. It is clear that mark infringements in good and service trades have disadvantaged various parties such as owners of the right to a mark, consumers and traders selling goods with well-known marks [3].

Various parties illegally and intentionally use well-known marks for their own benefits by misusing the good reputation of the well-known marks because many consumers want to use cheap or even very cheap goods using well-known marks. There are some factors, such as lack of public legal awareness, low purchasing power and low self-esteem of producers to use their own marks. This situation is then used by those who want to take advantages by producing and selling counterfeit goods using well-known marks.

Long economic crisis also becomes a factor that pushes many producers to combine original goods and counterfeit goods [4]. From their physical appearance, they are exactly same. Many people are interested in buying counterfeit goods because their price is cheaper than that is of the original ones. Furthermore, some counterfeit goods have super quality. According to consumers, the quality of counterfeit goods with super quality is almost same with that of the original goods. This situation, of course, benefits producers of counterfeit goods because they do not need to spend much money to build the image of their products and advertise them. Only by imitating the mark of an original product, they can produce and sell up-to-date product.

The use of well-known marks gives great economic benefit to producers of counterfeit goods because although communities have low purchasing power, they still want to look stylish and trendy. The counterfeit goodscan be easily found in big cities in Indonesia, including in Medan. They are sold freely on road side and traditional markets.

Sadly, it seems that the situation is not dealt with properly. Neither government nor law enforcers take measures to prevent and ban the production and trade of counterfeit goods. This shows that Law on Marks still cannot be implemented effectively.

\section{Problem}

Trade in counterfeit goods using well-known marks is rampant in Indonesia. Therefore, it is important to provide legal protection to owners of a well-known mark as an effort to enforce Law on Marks in the country.

This research aims to answer the following questions, What are factors influencing trade in counterfeit goods using well-known marks in traditional markets in Medan, What can be done to prevent trade in counterfeit goods using well-known marks in traditional markets in Medan, and How is law enforcement against trade in counterfeit goods using well-known marks.

\section{Research methods}

This research applied an empirical research method, relying on primary data from the field. The research respondents were traders selling counterfeit goods using well-known marks, especially counterfeit bags and shoes. The respondents were selected by using a purposive sampling technique [5]. Data in the research was collected by using a questionnaire which was distributed to traders and consumers. The questionnaire instruments were measured by using a 5-point likert scale [6].

This research was conducted in a number of traditional markets in Medan such as Petisah, Ramai, Cathay Shoe Central, Brayan and Central Market. There were total of 15 traders and 30 buyers who became the research respondents from each traditional market. 
Based on the findings of our preliminary survey, there were five traditional markets which met criteria set by the researcher. The criteria were that they are run under the supervision of Local Company Market of Medan City (Perusahaan Daerah Pasar Kota Medan) and and sell counterfeit bags and shoes using well-known marks.

Criteria of respondents are traders who sell shoes and handbags using well-known brands and have been trading for more than 5 years. Buyers who subscribe to buy and use artificial shoes and handbags with a well-known brand are asked directly at the study site [6]. The survey was conducted by distributing a closed questionnaire to the respondents.

\section{Discussions}

\subsection{Factors influencing trade in counterfeit goods using well-known marks}

There were some reasons why traders sold counterfeit goods using well-known marks. First, they did not understand Law Number 15 Year 2001 on Marks. So far, they had never been involved in the socialization of the law. Thus, they hoped government would allow them to sell counterfeit goods using well-known marks. They did not know that therewas a legal sanction that could be imposed on those who intentionally produced and sold counterfeit goods using registered well-known marks.

Table 1. Traders' understanding of Law Number 15 Year 2001.

Q : Do you understand Law on Marks?

\begin{tabular}{|c|c|c|c|c|c|}
\hline \multirow{3}{*}{\begin{tabular}{|l|} 
Valid \\
\end{tabular}} & & Frequency & Percent & ValidPercent & Cumulative Percent \\
\hline & Yes & 23 & 30.7 & 30.7 & 30.7 \\
\hline & No & 52 & 69.3 & 69.3 & 100 \\
\hline & Total & 75 & 100 & 100 & \\
\hline
\end{tabular}

Second, they did not understand that selling counterfeit goods using well-known marks violated the applicable laws or their conduct was illegal. Due to the lack of understanding of Law on Marks which was applicable nationally in Indonesia, they did not know that selling counterfeit goods using well-known marks was a criminal act.

Based on the the research findings, $57.3 \%$ of traders who were the research respondents answered that they did not know that selling counterfeit goods using well-known marks was illegal and could be imposed with a legal sanction.

Table 2. Traders' understanding of law violations related to the use of well-known marks for counterfeit goods.

Q : Do you understand that selling counterfeit goods is illegal?

\begin{tabular}{|l|l|r|r|r|r|}
\hline \multicolumn{2}{|c|}{} & \multicolumn{1}{|c|}{ Frequency } & \multicolumn{1}{|c|}{ Percent } & Valid Percent & Cumulative Percent \\
\hline \multirow{3}{*}{ Valid } & Yes & 32 & 42.7 & 42.7 & 42.7 \\
\cline { 2 - 6 } & No & 43 & 57.3 & 57.3 & 100 \\
\cline { 2 - 6 } & Total & 75 & 100 & 100 & \\
\hline
\end{tabular}

Third, traders sold counterfeit goods using well-known marks because selling such goods was more beneficial and easier. By selling counterfeit goods, traders gotmore profits. It was also easier for them to sell counterfeit goods using well-known marks because they were in high demand. Many traders in traditional markets sold counterfeit bags and shoes using well-known marks because many buyers were interested in such goods. Traders made more profits. Since the goods were in high demand, they could always renew their stock with up-to-date models. 
Table 3. The advantages of selling counterfeit goods.

Q : Do you get advantages from selling counterfeit goods?

\begin{tabular}{|l|l|r|r|r|r|}
\hline \multicolumn{1}{|c|}{} & Frequency & Percent & Valid Percent & Cumulative Percent \\
\hline Valid & $\begin{array}{l}\text { Yes. They are } \\
\text { easier to be sold }\end{array}$ & 29 & 38.7 & 38.7 & 38.7 \\
\cline { 2 - 6 } & $\begin{array}{l}\text { Yes. There are } \\
\text { more customers }\end{array}$ & 15 & 20 & 20 & 58.7 \\
\cline { 2 - 6 } & $\begin{array}{l}\text { Yes. We make } \\
\text { more profits }\end{array}$ & 27 & 36 & 36 & 94.7 \\
\cline { 2 - 7 } & No & 4 & 5.3 & 5.3 & 100 \\
\cline { 2 - 7 } & Total & 75 & 100 & 100 & \\
\hline
\end{tabular}

Fourth, law enforcers did not take proper legal measure to deal with the issue. Actually, they could play a vital role in the prevention of trade in counterfeit goods using well-known marks. The absence of legal measure by law enforcers would perpetuate the illegal practice. In this context, the law enforcers were actually not only policemen as investigators but also prosecutors and judges. However, traders who were the research respondents assumed that the law enforcers were only policemen.

Table 4. The lack of legal action.

Q : Have law enforcers ever taken any action?

\begin{tabular}{|l|l|r|r|r|r|}
\hline \multicolumn{2}{|c|}{} & Frequency & Percent & Valid Percent & Cumulative Percent \\
\hline Valid & Yes & 17 & 22,7 & 22,7 & 22,7 \\
\cline { 2 - 6 } & Never & 58 & 77,3 & 77,3 & 100,0 \\
\cline { 2 - 6 } & Total & 75 & 100,0 & 100,0 & \\
\hline
\end{tabular}

\subsection{Factors influencing buyers to buy counterfeit goods using well-known marks}

There were also some reasons why consumers bought counterfeit goods using well-known marks. First, they did not understandthe applicable laws, especially Law Number 15 Year 2001. This could be seen from research findings presented in table below.

Table 5. Consumers' understanding of Law Number 15 Year 2001.

Q : Do you understand Law on Marks?

\begin{tabular}{|c|c|c|c|c|c|}
\hline \multirow{3}{*}{ Valid } & & Frequency & Percent & Valid Percent & Cumulative Percent \\
\hline & Yes & 17 & 11.3 & 11.3 & 11.3 \\
\hline & No & 133 & 88.7 & 88.7 & 100 \\
\hline & Total & 150 & 100 & 100 & \\
\hline
\end{tabular}

Second, consumers bought counterfeit goods using well-known marks because they could be easily found in traditional markets. Meanwhile, if they wanted to buy original goods, they had to go to a super market or a super mall which is quite far from their house. In addition, branded goods could also be bought from distributors, special dealers or agencies with a membership system.

Table 6. Places where counterfeit goods are sold.

Q : Where can you buy counterfeit goods?

\begin{tabular}{|c|c|c|c|c|c|}
\hline & Frequency & Percent & Valid Percent & Cumulative Percent \\
\hline \multirow[t]{4}{*}{ Valid } & Malls & 32 & 21.3 & 21.3 & 21.3 \\
\hline & Road side shops & 18 & 12 & 12 & 33.3 \\
\hline & Online & 39 & 26 & 26 & 59.3 \\
\hline & Traditionalmarkets & 58 & 38.7 & 38.7 & 98 \\
\hline
\end{tabular}




\begin{tabular}{|l|l|r|r|r|r|}
\hline & Others & 3 & 2 & 2 & 100 \\
\cline { 2 - 6 } & Total & 150 & 100 & 100 & \\
\hline
\end{tabular}

Third, consumers bought counterfeit goods using well-known marks because they were affordable and cheaper than original goods. Due to their low income, consumers prefered to buy counterfeit goods because they were affordable and cheaper than branded ones.

Since counterfeit goods could be easily found in traditional markets, consumers were more interested in buying them. Even, they intentionally bought counterfeit bags and shoes whose models and marks were same with those of the original ones for collection so that they could use them in various events. In addition, they thought that it was better to buy counterfeit bags and shoes because they could be used in their daily activities. The research respondents also said that they always bought counterfeit bags and shoes with the latest design and model because they were cheap. By doing that, they could always catch up with the latest trend in the fast changing world.

Table 7. Consumers' reasons for buying counterfeit goods.

Q : Why do you buy counterfeit goods?

\begin{tabular}{|l|l|r|r|r|r|}
\hline \multicolumn{2}{|c|}{} & Frequency & Percent & $\begin{array}{c}\text { Valid } \\
\text { Percent }\end{array}$ & $\begin{array}{c}\text { Cumulative } \\
\text { Percent }\end{array}$ \\
\hline Valid & To be used in daily activities & 42 & 28,0 & 28,0 & 28,0 \\
\cline { 2 - 6 } & To follow the trend & 23 & 15,3 & 15,3 & 43,3 \\
\cline { 2 - 6 } & $\begin{array}{l}\text { Their price is cheaper than } \\
\text { those of the original ones }\end{array}$ & 85 & 56,7 & 56,7 & 100,0 \\
\cline { 2 - 6 } & Total & 150 & 100,0 & 100,0 & \\
\hline
\end{tabular}

Fourth, consumers bought counterfeit bags and shoes because they wanted to avoid possible big loss. They said that they bought counterfeit goods because they could easily sell them again if they disliked them. By doing that, they could easily get their money back.

Table 8. The advantages of buying counterfeit goods for consumers.

Q : Do you get advantages from buying counterfeit goods?

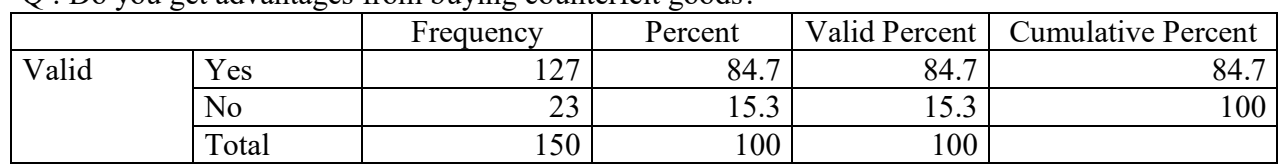

\subsection{Efforts to minimize trade in counterfeit goods using well-known marks in traditional markets in Medan}

It is important to improve traders' and consumers' understanding of Law on Marks through socialization and legal extension. It is hoped that by improving their understanding of the law, their legal awareness will also raise and law enforcement is more effective.

It is also important to improve the self-esteem of local producers so that they want to use their own mark on their products. It is important to improve the quality of their products so that local consumers will be interested in buying them. It is also urgent to help local producers register their marks to ensure that they will get legal protection for the right to a mark used on their products. All of these activities can be implemented as an effort to prevent and minimize trade in counterfeit goods using well-known marks. Mark registration is a key requirement to get legal protection.

Chart below describes how local producers can be assisted to register their marks as an effort to increase the production of and trade in local products using their own marks in 
traditional markets in Medan, minimize trade in counterfeit goods using well-known marks and increase trade in local products using a registered mark.

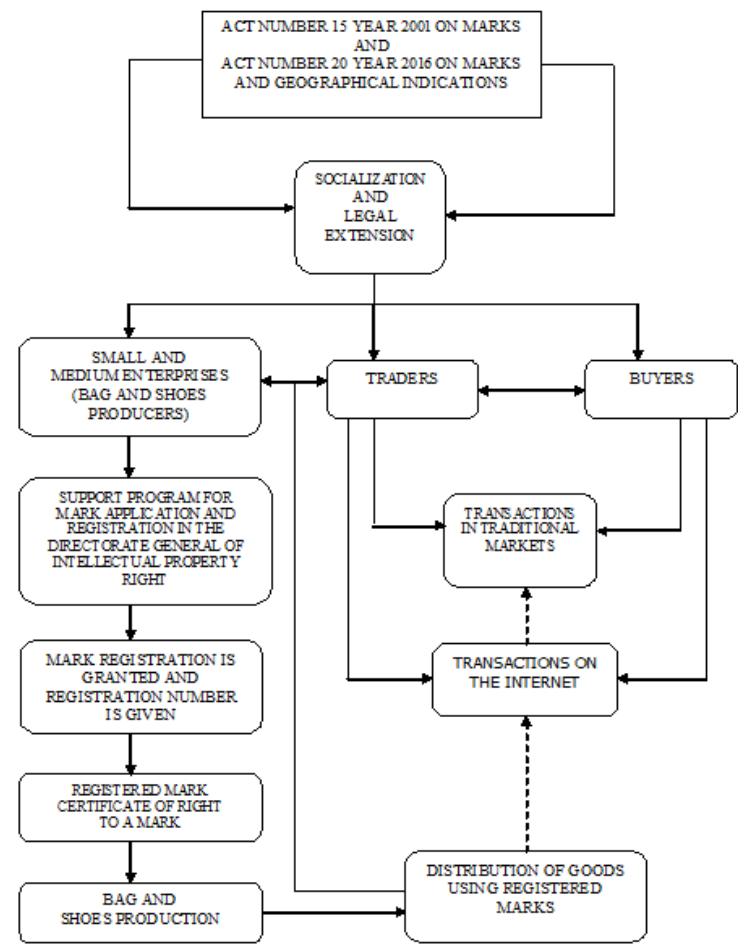

Fig. 1. Chart for increasing local products using a registered mark

Chart above can be further described as follows:

1. The first is socialization and legal extension on Law Number 15 Year 2001 on Marks and Law Number 20 Year 2016 on Marks and Geographical Indications.

2. The second is supporting local producers (small and medium enterprises producing bags and shoes) to apply for registration of a mark. It is important to support producers to increase the quality of their products in order to get consumer trust in using local products, especially shoes and bags. The support must continue until the mark registration is granted by and they get registration number from the Directorate General of Intellectual Property Rights, local products use registered mark and producers get the right to a mark.

3. Producers directly distribute the local products to traders. Then, traders sell the products in traditional markets or on the internet. Producers also can directly sell their products in traditional markets or on the internet without an intermediary (trader).

\subsection{Law enforcement against the use of well-known marks on counterfeit goods}

A constitutive system is currently used in mark registration system in Indonesia. This system has some strengths in term of legal certainty. According to the system, mark owner is the one who has registered it. This is known as presumption of ownership [7]. So, mark registration gives the one who has registered it a right to the registered mark. Thus, other 
parties have to respect it. According to the system, mark registration is a key requirement to get legal protection of the rights to a mark.

According to constitutive registration system, law enforcement against registered mark infringement in Indonesia can be done by filing a civil or a criminal lawsuit or through an alternative dispute resolution outside the court [8]. This is also applicable to law enforcement against trade in counterfeit goods using well-known marks [9].

As a comparison, we can see legal protection of the right to a mark in Benelux which also applies civil law like Indonesia. The protection of mark in Benelux is regulated by Benelux Law on Marks. Under the law, a mark can only be protected if it has been registered in the Benelux Office for Intellectual Property (BPOP) in The Hague. If there is an addition to name, logo or emblem and with certain requirements, shape, color, aroma or package of a product can also be protected as a mark [10].

Under Benelux Law on Marks, marks in Benelux are protected in Benelux countries. Since mark registration in Benelux is considered as a unit, an application applies in all territories [10]. In principle, mark registration system in both Indonesia and Benelux uses a constitutive system. The difference of mark registration in Indonesia and Benelux only lies in its procedures and phases.

Law enforcement against well-known mark infringement in Medan is done through dispute settlement in the Commercial Court. However, the research found that there was no well-known mark infringement case handled by Medan Commercial Court from 2016 to 2017. So far, the court only handled cases of registered mark. Most of well-known mark infringement cases were handled by Central Jakarta Commercial Court. Although Medan is one of big cities in Indonesia, well-known mark infringement cases were so far handled in Jakarta. In addition, since mark infringement is categorized as an ordinary offense, police can directly investigate a well-known mark infringer by using the criminal law and do not need to wait complaint or report from communities or parties concerned. Mark infringers use different motives in mark infringement cases such as imitating and counterfeiting wellknown marks because theywant to get great advantages from the good reputation of a wellknown mark. Criminal sanctions for the infringements of a well-known mark and a registered mark are regulated under Law Number 15 Year 2001 on Marks [11]. Different sanctions such as imprisonment, fine anddeprivation of the rights to a mark may be imposed on any party which is proven to have violated the law.

\section{Conclusions}

\subsection{Summary}

There are some reasons why traders sell counterfeit goods using well-known marks. The research found that traders sold counterfeit goods using well-known marks because they did not understand Law Number 15 Year 2001 on Marks. They also did not know that selling counterfeit goods using well-known marks was a crime. In addition, counterfeit goods were in high demand so that they could give them high profit.

There were also some reasons why consumers bought counterfeit goods using wellknown marks. They said that counterfeit goods using well-known could be found easily. In addition, they were cheap and affordable. They also bought counterfeit goods for collection.

It is important to improve traders' and consumers' understanding of Law on Marks through socialization and legal extension. It is hoped that by improving their understanding of the law, their legal awareness will also raise and law enforcement is more effective.

It is also important to improve the self-esteem of local producers and the quality of their products so that local consumers will be interested in buying them. It is also urgent to help 
local producers register their marks to ensure that their rights to a mark used on their products can be protected legally. All of these activities can be implemented as an effort to prevent and minimize trade in counterfeit goods using well-known marks in traditional markets in Medan.

\subsection{Recommendations}

Local producer supposed to have a registered trademark of their products to get the legal protection. This legal protection is required to improve the reputation of the brand. It's time for the local government of Medan (Pemerintah Kota Medan) to help and provide the technical guidance for local producer in improving the products quality which impacts to the consumer trust enhancement to buy local product

\section{Acknowledgements}

The research was funded by the Directorate of Research and Community Service of the Directorate General for Research and Development of the Ministry of Research, Technology and Higher Education in accordance with the Funding Research and Community Service Agreement for the Fiscal Year 2018.

\section{References}

1. A. Herviandi, E. Susilowati, R. Njatrijani. Diponegoro Law Journal 6, 1 (2017)

2. A. Sutedi. Hak Atas Kekayaan Intelektual (Sinar Grafika, Jakarta, 2009)

3. J. Mamahit, Jurnal Lex Privatum, 1, 3 (2013).

4. Blogspot Hukum Perlindungan Konsumen Perlindungan Merek [online]. Retrieved from https://duniathoto.blogspot.co.id/2010/12/hukum-perlindungan-konsumen.html

5. R.H. Soemitro. Legal Research Methodology and Jurimetrics, Fifth Edition (Ghalia Indonesia, Jakarta, 1994)

6. B. Prasetyo, L.M. Jannah, Metode Penelitian Kuantitatif (PT. Raja Grafindo Persada, Jakarta, 2006)

7. Article 3 of Act Number 15 Year 2001 on Marks stipulates that the Right to a Mark is the exclusive right granted by the State to the owner of a Mark which is registered in the General Register of Marks for a certain period of time, to himself use said Mark or to grant permission to another party to use it.

8. See Article 76, Article 84 and Article 89 of Act Number 15 Year 2001

9. A. Sulistiyono. The Existence and Resolution of Intellectual Property Right Disputes (LPP and UPT Penerbitan dan Pencetakan UNS Press, Surakarta, p. 49, 2008).

10. I.B. Maulana, E. Flohil. A Short Comparison of Mark Protection in the Netherlands and in Indonesia (Alumni, Bandung, 2018)

11. See Article 100 of Law Number 15 Year 2001 on Marks. 